\title{
Martial Arts Tourism of the "Europe-Far East" Direction, in the Opinion of Grand Masters
}

\author{
Abel A. Figueiredo ${ }^{1}$, Wiesław Błach ${ }^{2}$, Zbigniew Bujak ${ }^{3, * \mathbb{D}}$, Roland J. Maroteaux ${ }^{4}$ \\ and Wojciech J. Cynarski ${ }^{5}$ (i) \\ 1 Polytechnic Institute of Viseu, School of Education, 3504-510 Viseu, Portugal; abel.figueiredo@esev.ipv.pt \\ 2 Department of Sport, University School of Physical Education, 51-612 Wrocław, Poland; wieslaw.judo@wp.pl \\ 3 Faculty of Physical Education and Health in Biała Podlaska, Józef Piłsudski University of Physical Education \\ in Warsaw, 21-500 Biała Podlaska, Poland \\ 4 Union Nationaled'Aiki-jujutsu\& Disciplines Associées, 49400 Avignon, France; unada.cos@takeda-ryu.net \\ 5 Institute of Physical Culture Studies, College of Medical Sciences, University of Rzeszow, \\ 35-310 Rzeszow, Poland; ela_cyn@wp.pl \\ * Correspondence: bujakz@o2.pl
}

Received: 31 August 2020; Accepted: 20 October 2020; Published: 25 October 2020

check for updates

\begin{abstract}
Martial arts tourism is a form of cultural, sports and educational tourism that requires special recognition; particularly important is knowledge about martial arts. The sources of this practical knowledge are especially high-ranking masters. The scientific problem raised here involves the issue of high-ranking martial arts teachers taking trips for their own studies (to acquire knowledge and skills) and teaching others. Some of the questions addressed include how often the trips occur (single, sporadic, or multiple, regular), what their effects are, and what their meaning is-in the opinion of these experts. The "Martial Arts Tourism" questionnaire was addressed to $\mathrm{N}=12$ people, masters/teachers of high-rank in martial arts (level 7-10 dan/toan) who live and teach in Europe and the USA, but come from Europe. They are the holders of the highest degrees in Chinese, Japanese and Korean styles. Further questions were asked through direct correspondence. The collected statements were usedby means of qualitative analysis_as in the method of 'expert courts'/'competent judges'. The respondents in most cases undertook trips from Europe to East Asia for their own learning. They teach themselves mainly in their own countries and in Europe. Stays rarely lasted over two weeks. The respondents are convinced of the legitimacy of this type of trip, and believe that the trips are very helpful on the way to mastery. None of the respondents mentioned the material forms of cultural heritage pertaining to martial arts as motives for the trips. Therefore, the ability to visit historic places is a marginal concern. The trips were directly linked to a career path and self-improvement in martial arts, learning or teaching.
\end{abstract}

Keywords: tourism; martial arts; combat sports; way to mastery; grand master

\section{Introduction}

In the era of globalization, apart from crisis periods, such as wars or pandemics, members of societyeagerly travel to, visit, or explore new places, seeking new knowledge and impressions [1]. Cultural tourism, educational tourism and similar forms of non-entertainment tourism [2] (pp. 11-21) fit into this kind of fashion or need, which is often artificially fueled. One form of cultural tourism is martial arts tourism (as a socio-cultural phenomenon).

Martial arts tourism, as a form of cultural tourism, is part of a wider discussion on the useof free time, the relationship between work and leisure, and related self-realization [3-5]. In this way, it is similar to sports tourism. In both cases, there is also a tension between the protection of tangible 
and intangible cultural heritage and travel, tourism (as a social fact) and commercialization [1,6]. Sports and recreational activitiesare often attractive additions to a tourism or hotel offer. Here, however, they havean autotelic value - an independent goal, that is, active forms of sports tourism.

In scientific interpretation, martial arts tourism is derived from general tourism theory, tourism geography, tourism sociology, martial arts theory and martial arts sociology [7] (p. 101). "Martial Arts Tourism" is the title of the fourth chapter of the book Meetings, conflicts, dialogues: analysis of selected areas of physical culture and cultural tourism. The author offers, in addition to examples of travel undertaken by martial arts practitioners and the cultural climate of the "place of the way" (Japanese $d \bar{o} j \bar{o})$, descriptions of the specific architecture of martial arts objects and interior design with old Japanese symbolism (coats of arms of samurai families) [7-10]. In the same book, subsequent chapters are devoted to the problems of meeting and cultural dialogue, educational travel and psychophysical education, i.e., indirectly explaining the phenomenon of martial arts tourism as cultural and educational/self-realization tourism [7] (pp. 144-239).

The problem of international and intercultural dialogue was addressed by the editors and co-authors of the book International Dialogue: Global, European, National and Multicultural Dimensions of Tourism [11]. Martial arts tourism is indeed participating in this dialogue. In this book, the concept of "self-educational tourism" is discussed, and it makes a contribution to the tourism geography of East Asian martial arts (a series of maps) with historical photos documenting the journeys described [12].The book also includes the results of strictly empirical research on the activity of people practicing aikido and taekwon-do in terms of their participation in martial arts tourism (meetings, seminars and sports camps) [13].

A new monograph, entirely devoted to martial arts tourism, discusses martial arts tourism from the perspective of historical, typological, geographical, sociological and relational systems $[14,15]$. We find here rich photographic material due to the author's use of visual sociology [16]. Significantly, this type of tourism (which is a form of cultural, educational and sports tourism) is included in the General Theory of Fighting Arts [5,17]. It is a form of practical implementation of the idea of the Way of the Warrior. It is the Tao, which isa moral pathway towards self-perfection, in addition to being Bushido. The sustainability of this type of tourism should manifestin the maintenance of the cultural tradition, cultural monuments of this tradition in the countries of origin of individual martial arts, and in relation to the countries which are the sources of martial arts. These trips to the sources, to the places of the cultural context of the emergence of individual schools and styles, constitute a significant aspect of this type of tourism.

The scientific problem explored in the present studyis the issue of trips undertaken by high-ranking martial arts teachers-Grand Masters-for their own studies (to acquire knowledge and skills), and for teaching others. How frequentare these trips-single and sporadic or multiple and regular? What are their effects? What is their meaning-in the opinion of these experts?

\section{Materials and Methods}

As presented by Abel Figueiredo [18] (pp. 21-22), we can note the increasingly scientific look into various areas, from biological to socio-axiological perspectives, of martial arts and combat sportsin order to perform interpretative exercises, whereby explanation and comprehension evolves in a hermeneutic sense to a certain "praxiological hermeneutic" [19] at theorganizational level, and is usually supported by participant observation [20], which is made possible by its observer-observed relational analogue, similar tohow it was used by Wacquant [21].

The basic method used in this study is the narrative interview [22], stimulating the participants to make a certain hermeneutics of self-representation. The authors use the method of participant observation or observant participation [23], participating directly in the activity of the martial arts and combat sports environment and the phenomenon of martial arts tourism. These are the basic qualitative methods used in social and tourism research [24]. 
The practitioners of martial arts usually follow one or more disciplines during a certain time of practice, developing a certain recognized level of proficiencyin a specific martial art. Because we are focused on understanding touristic trips made by martial arts practitioners, and as an exploratory study, we limitedour consideration to European-based practitioners of Asian martial arts. In that way, because of the distance from the original country of the martial art and the residential country of the practitioner, we expect to explore also a certain touristic motivational energy derived from territory and cultural distancing. Furthermore, because we need to understand the interpretations of practitioners during a long period of years, we decided to find actual practitioners with high grades in their disciplines, and also with certain responsibilities in their institution's development, and because of that, we limited our consideration to participants that continue the practice and are on the last step (or near the last step) of attaining the highest ranks of the discipline. Finally, the research project found that the participants could also be invited to act as authors because of their scientific backgrounds in martial arts studies.

The "Martial Arts Tourism" exploratory questionnaire was addressed to $\mathrm{N}=12$ people, high-level martial arts teachers (7-10 dan/toan, Grand Masters), living and teaching in Europe and the USA, but coming from Europe. They are the holders of these highest degrees in Chinese, Japanese and Korean styles. They represent 10 different styles, with a predominance of varieties with Japanese and Okinawan-Japanese provenance. In these schools, styles and organizations, a system of dan degrees is used, while in the martial arts traditions of other countries (e.g., China), this is used much less often; then it is difficult to determine who is the master of the highest rank.

Asked (by email) as follows:

“Please, make statements about your trips for martial arts carried out to learn or teach-where (countries, regions or cities), how many times, with what effects? I am also asking for some general comments about such trips, their directions, motives and goals. I address these questions to a group of 10 high-level experts. The answers will be used for scientific purposes only."

Then the issue was specified and further questions were asked by direct e-mail correspondence or by phone. The collected statements were prepared by qualitative analysis. In the period of March-April 2020, N = 10 unambiguous answers were collected. These statements can also be treated similarly to the method of "expert courts" or "competent judges". The remaining two people referred researchers to appropriate, available materials. Since the originator of this project directly knows all these people and their general activity in the area of martial arts and combat sports, the lack of precise numerical data only slightly burdens the analysis with an error, which is also inevitable in strictly quantitative research (such as in a diagnostic surveys).

As in the method of expert courts/competent judges, we selected 7-12 people who may be considered particularly competent in a given case. We analyzed and compared their statements. This is a qualitative merit, as is the participant observation.

The next photos show the cultural context outside of martial arts (Figure 1), the practice of martial arts (Figure 2a), and a connection with material heritage-building importance for the functioning of martial arts (Figure $2 b$ ).

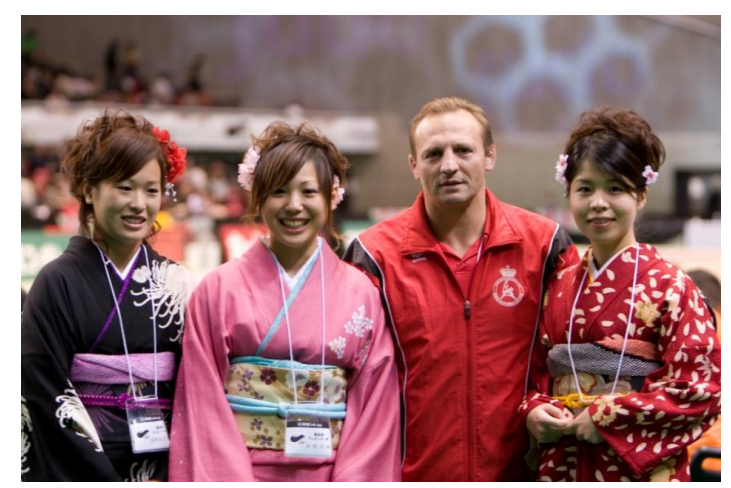

Figure 1. Dr. WiesławBłach among Japanese students at judo competitions in Japan (courtesy of W. Błach). 


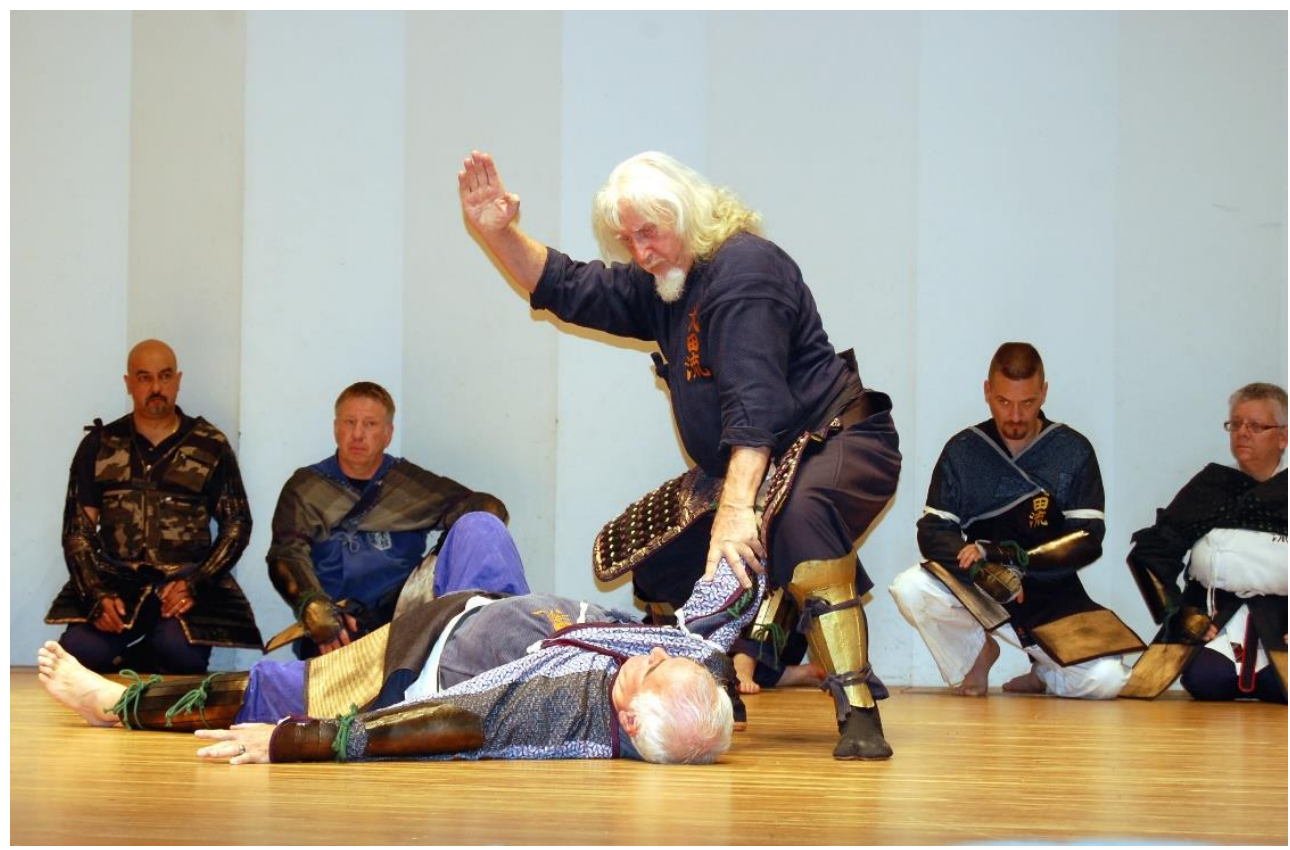

(a)

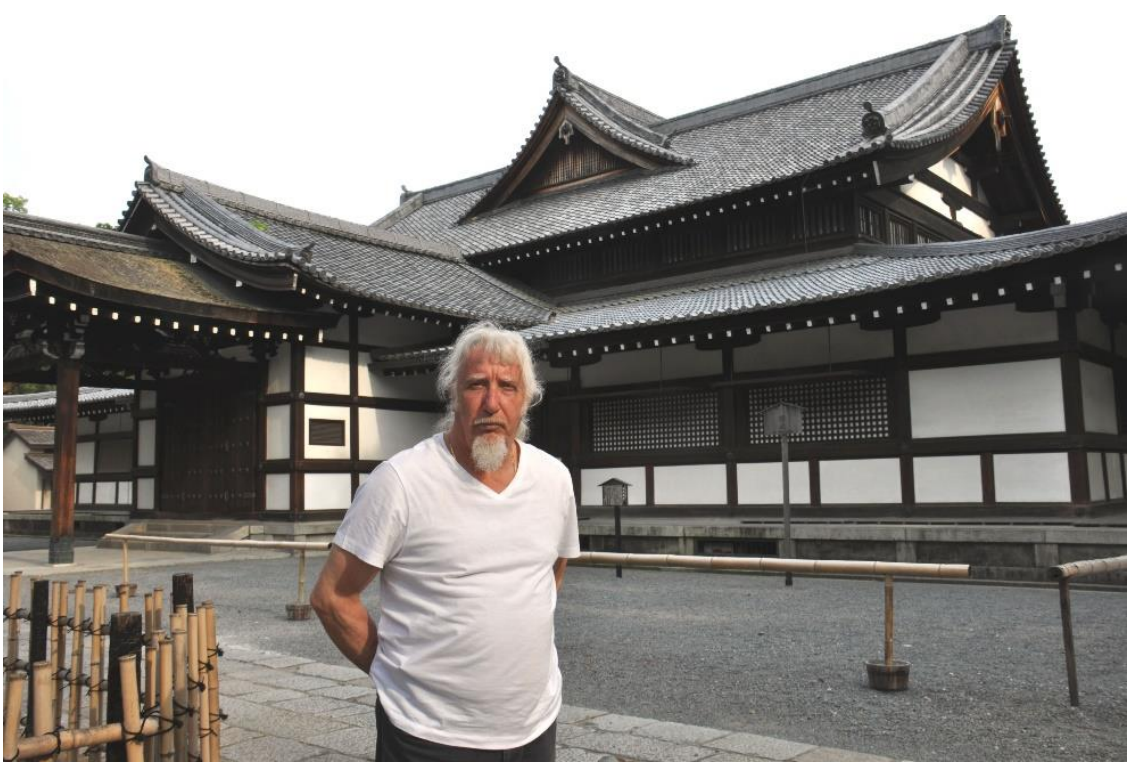

(b)

Figure 2. (a) Demonstration in Japan, 2014. Old techniques of the Takeda-ryu school; (b) Dr. Roland Maroteaux in front of the Butokuden building. Kyoto, Japan 2009.

\section{Results}

\subsection{Trips for Learning}

We provide the statements of the respondents in alphabetical order, according to surnames.

Błach W.-He went to Japan mainly for learning (Figure 1). Substantially, "The judo man could visit Japan, as a player, coach, participant of scientific conferences, repeatedly. For W. Błach it was 40 different visits, not only at the Kodokan Institute." He also visited Kodokan (Tokyo), as discussed not only in [25,26] but also in [14] (pp. 116-122). 
However, in this case, each of his trips, whether as a fighter, coach or researcher, contained a strong theme of self-improvement, i.e., learning and acquiring new competences. As he says, these were as follows.

(1) Typical scientific trips, for self-study, and for practical studies of martial arts and combat sports, as follows: Japan - three times University of Tsukuba 2001-2004 (7-14 days each); Russia (Moscow), State Russian University of Physical Culture, Sport and Tourism—six times in the years 2002 to 2005 (3-5 days each); Slovakia (Banska Bistrica), Matej Bel University, 2012-2017-five times for 2-3 days; Belgium (Vrije University) -2006-2008 for 3 years for 3-7 days a month; Belarus (Minsk), College of Sport Coaches-three times in 2017, 2018 and 2019 (4 days each).

(2) Judo training trips, sambo, jujutsu, for self-study, for practical studies of martial arts and combat sports. Judo training seminars and conferences: Brazil (Rio de Janeiro) -2007 and 2013 (after 7 days); Croatia (Porec, Zagreb) -2014-2019 (eight times) (3-4 days each); Italy (Rome)-2018-2019, two times for 4 days; Japan (Tokyo) -2010-2019, seven times for 7-10 days; Qatar (Doha) -2020, 4 days. Sambo: Russia (Kstovo), World Sambo Academy—2005 (7 days). Jujutsu: Vietnam (Danang) -2017, 7 days.

(3) Judo sports trips (as a player until 1992, as a coach from 1993 to today): Japan-about 40 times (competitions, training camps) in 1982-2019 for 7-21 days; South Korea-1985 and 1988, 10-14 days each; Australia-2000, 14 days; South Africa-2011, 10 days; Canada (Hamilton, Montreal)—1993 and 2006, 10 days each; USA (Colorado Springs, Atlanta)—1986 and 1996, 14 days each; Brazil (Sao Paulo, Rio de Janeiro)—2006, 2007 and 2013, 10-14 days each; Cuba (Havana)—2013, 10 days; Egypt (Cairo)—1993, 10 days; UAE (Abudhabi) -2011, 7 days; Israel (Telaviv)—2013, 2017 and 2018, 7-14 days each; Kazakhstan (Astana) -2015, 10 days; China (Beijing) -2001, 14 days; Europe (excluding Iceland, Ireland, Monaco, Liechtenstein, Northern Macedonia, Andorra, Latvia, Moldova, Malta and Faroe Islands) - a few or several or several dozen times in each country in the period 1978-2020. In addition, there were conferences and seminars in Poland (Warsaw, Gdańsk, Rzeszów, Poznań, Gliwice, BiałaPodlaska, Opole, Rydzyna, Spała, Kraków and Katowice).

In total, there were trips made to many countries of the world, associated with a sports and coaching career, functions in national and international sports organizations, and work at a university. They all involved their own martial arts and combat sports studies.

Bujak Z.-Travelled twice to DPRK/North Korea ("typically for training for 2 weeks, once judging during WCh and training - 1 week"). In total, 10 trips to international training (in the ITF taekwon-do this is called the International Instructor Course) in Europe (Italy and Spain (several times), Hungary, Sweden, Germany, Latvia, the Czech Republic and Scotland (UK)).

About 15 times hewas refereeing at ECh in taekwon-do, and 8 times at WCh ("Judges' briefing/training was also technical training"). "I still forgot to add Argentina. Apart from Latvia (Riga), all trips were related to learning and improving technical and tactical skills. It will probably be useful to know that I have practiced 5 times in 2-day seminars with the author of the name taekwon-do Choi Hong Hi." As such, he made were trips abroad to 10 countries.

Cynarski S.-Travels around Poland often, also to four other European countries (France-11 times, Germany -3 times, Belgium -1 time, and Czech Republic -1 time). Most often they were weekly seminars with teachers from Japan, France, Belgium and Russia [14] (pp. 19-26). For many years he has been the organizer of national and international trainings, to which he invites masters/teachers, including foreign ones. He has studied many times under the masters who come to him directly.

Cynarski W.-Around Polandmany times, and to eight European countries (Germany-25 times, France - 4, Czech Republic and Romania—2 each, Austria, Belgium, Slovakia and Hungary-1 each) and three Asian countries (Japan—five times, China/Shaolin and Thailand/Bangkok—one each) [27]. The durations of stays were from 2 days to 3 months. He adds: "In addition to trips for martial arts, learning or teaching, I also went to tournaments—as a fighter, coach, sports referee, activist, or as a fan. I supported, among others at ECh Kyokushin karate IKO (International Kyokushinkai Organization) in Katowice, WCh JJIF (Ju-Jitsu International Federation) in Wrocław, WCh World Taekwondo (WTF) in Muju (South Korea) and World Cup ITKF (International Traditional Karate Federation) in Warsaw 
and at one large kickboxing gala, also in Warsaw. Each trip was for me a form of broadly understood martial arts studies."

Drewniak A.-To the Netherlands (exam for 2 dan in karate Kyokushin) and to Japan (at least four times; the second time it was a 15-month stay). Obtained 4-6 dan in Japan [28].

Figueiredo A.-Around Portugal, for studying various martial arts, many times, then to Japan (different cities, 14 times), Brazil (Sao Paulo), USA (Los Angeles), Canada (Toronto), China (Hong Kong), and seven European countries (London, UK-many times, also Oxford, Belgium, France, Germany, Spain, Sweden and Switzerland).

Kernspecht K.-Studied in Germany, England (UK) and Denmark, also in California (USA) and China (Hong Kong and Taiwan) [29] (pp. 335-357). Despite having a 10thdegree in WingTsun, he is still learning. As he wrote in reply to the questionnaire: "I was in Asia for 3 weeks during the outbreak of corona [virus]. When I was in Singapore to investigate several Wing Chun and Wing Tsun styles there, I got the warning that I could not go on to Foshan, China, where I had an invitation to meet the first students of Yip Man who were still alive or more correctly their students. So instead of going to China proper I went with my daughter Natalie, also a WingTsun master (EWTO) and PhD in Sports Education (State University of Plovdiv. BG) to Malaysia where I researched the wing chun clubs as well as the 5 Ancestors Fist Style and the so-called Wu Mei Style, who claim to be some sort of source of Wing Chun. As is my habit, I always cross hands with the teachers of the styles I meet to find out on touch what they really have to offer. What I am after is fighting ability! Also I researched two Chinese Styles that now are extinct in China and only exist in Malaysia, one of these styles I have been studying with Nathalie for over 6 years from the Grandmaster. The style's name is I LikChuan and the best fighter and GM is Jimmy Heow. We meet a couple of times per year to train for 2 weeks or more".

Maroteaux R.-He practiced first in France. Then, he went to Japan (26 times, from a week to a month, practicing $6-8 \mathrm{~h}$ a day) and to China (twice). See Figure $2 \mathrm{a}, \mathrm{b}$.

Samitowski L.-Training and sports camps in Poland, Hungary and the Netherlands, then after the USA he also went to Japan (already as a coach), and many times he went to China (Shaolin). For the third dan of karate Kyokushin he had to pass the exam twice-in Papendal (Netherlands) and once again in Bialystok (Poland) during the Summer School of 1987. So, on some trips he was forced to take master's degrees where this was possible. Living in the USA, he travels to China to study qigong and Chinese traditional medicine. He believes that the master of martial arts should have such knowledge and skills $[30,31]$.

Sieber L. and Sieber H.-After Germany, they traveled many times to Spain (five times), to the USA (once), and to Japan (a more tourist-like, 10-day stay) (once) [28,32,33].

Słopecki J.-Many times to Poland, and several times to Austria and Germany. One of his teachers was the Austrian GM Franz Strauss, 10 dan [34,35].

These are examples of different varieties of the "way to mastery". The comparison, evaluation and summary can be found further in the analysis (point 4).

\subsection{To Compete, to Coach, to Lead, to Research and to Teach}

Błach W.-Teaches as a trainer, especially in Poland and Belgium, and as the technical director of EJU, and is also active in other European countries. He also presents papers at scientific conferences, exchanging his knowledge in a specialist environment.

Bujak Z.-A total of $\mathrm{n}>100$ times to Poland plus trips to several countries. In particular, these were as follows: approximately 30 training trips to Poland, conducting classes with fighters and coaches at the invitation of club leaders; about 50 trips as a technical examiner (individually for student grades and as a member of the commission for grades 1-6 dan); and lectures (10 times) on taekwon-do instructor and trainer courses. "I have been running taekwon-do camps in summer and winter since 1989, which are attended by players and instructors of friendly clubs (I run technical-tactical or technical classes-mainly formal trainings for instructors)". He lectures and exams only in Poland. "I tested 
once in Germany, but most often I refused because of lack of time. At the ITF, you must always obtain the consent of the Technical Committee for conducting seminars and examinations abroad."

Cynarski S.-He has been in Polandmany times $(\mathrm{n}<100)$. He was the organizer of many training seminars, national and international, in his dojo in Tarnów (Poland).

Cynarski W.-In Polandmany times $(\mathrm{n}<100)$, and in Europe in up to 12 countries (Germany — eight time, Czech Republic—six, Portugal—five, Slovakia and Italy—three each, and Austria, Belgium, Finland, Ireland, Russia, Romania and Hungary-1 each). Outside Europe-5-(Japan-4, China-2, Korea, Thailand, USA/Florida—once each). They were practical/workshop, theoretical (lectures) or mixed forms $[26,27]$.

Drewniak A.- - Has been round Poland many times, to neighboring countries (Ukraine, Russia, Lithuania) and other, mainly European countries (as an examiner, trainer and activist).

Figueiredo A.-Around Portugal as a competitor, coach, expert leader, researcher and teacher ( $n>100)$. As a karate competitor: to Belgium-one time, Japan-two. As karate assistant teacher and director: to London, UK-eight times, Greece-two times and Slovakia—one time. As scientific and technical expert of martial arts: two times to Japan (conferences), and several times to Poland, France, Italy, Germany and Spain. He has been in Hong Kong and in Canada as well. A total of seven European countries and three non-European countries, plus Japan.

Kernspecht K.-Teaches basically in Europe, especially in Germany, Bulgaria and the UK. He organizes large training seminars, firstly at Langenzell Castel, and alsoin Heidelberg and Hockenheim (Germany). Every year, people who practice WingTsun kung-fu and Latosa/Newman escrima from Europe and outside Europe come here.

Maroteaux R.-Around Francemany times ( $\mathrm{n}>100$ ), and to Europe to most countries (most often to Romania, where he conducted international training seminars); also to 11non-European countries (Singapore, Cuba, Algeria, Tunisia, Morocco, USA, Canada, Guadeloupe, Madagascar, India and United Arab Emirates).

Samitowski L.- In Polandmany times $(\mathrm{n}<100)$. Numerous trips to sports competitions as a coach of the Polish team, then with the US representation, also as a trainer [30,31].

Sieber H.-Around Germanymany times ( $\mathrm{n}>100)$, and after to three European countries (Spain-15, Austria-5, Poland-1), then outside Europe once (USA). Most often he travels and teaches with his husband, Lothar.

Sieber L.-Around Germanymany times ( $\mathrm{n}>100)$, after to three European countries (Spain-15, Austria-5, Poland-2), and outside Europe-1 (USA). They were 2-day, weekly and longer stays [32].

Stopecki J.-After Poland (many times $(\mathrm{n}<100)$ ) he went to three other European countries (Germany-over 50 times in 25 years, Austria-5, Italy-2). Most often they were 2-3-day stays [36,37].

\subsection{Path of the Warrior: Shihan Abel Figueiredo}

Dr. Abel A. Figueiredo, shihan of Goju-ryu, sent this comprehensive account, which we shall quote in full (as below).

\subsubsection{Martial Arts Introduction Cycle}

I born in Luanda (Angola as Portuguese Colony) in 1964 and moved to Portugal in 1974. My first martial arts (MA) contacts started in Portugal, on School when I was 13 years old in Vila Nova de FozCôa with "wrestling" trainings and a first participation in a Scholar Sports event in Gouveia (my first trip linked with Martial Arts participation in a national tournament in 1977).

After moving to Viseu in 1979 I started the regular practice of my second MA activity with Mr. Walter Pestana, practicing a mixed Kung Fu + Karatedo methodology named "Kung Do Te" by a Portuguese instructor, Mr. Ruy de Mendonça living in Lisbon. On the mat of Kungdote, during this 1980/81 period, I made 3 trips to Lamego, another city in the region, to participate on gradings and seminars organised by the club dojo. This experience made me understand Bruce Lee as movie 
star, practitioner and author, and made me choose secondary school studies in Sports for better understanding the art.

Because Mr. Walter Pestana, my first instructor in Martial Arts, have moved out from Viseu in the middle of 1981, stopping the regular trainings, I started the regular practice of my 3rd MA experience, karatedoGoju-ryu in 1981 with Mr. José Oliveira. The only travels I made between 1981 and 1984 motivated by Martial Arts have been to Algarve (to train with Walter Pestana) and to Lisbon (to train with Mr. Ruy de Mendonça on Kung Do TeHonbu Dojo, and with Jaime S. Pereira the leader of a Gojuryu Association) all of them organised by myself and not by the club. Also a process of fencing and judo practice in Viseu, linked with nunchaku practice, made me understand basics of fighting and use of one hand weapon.

FIRST CONCLUSIVE COMMENT: I feel this first cycle made an eclectic modelling construction of fighting understanding. Travels where only in Portugal because of the practice skills improvement. My travels memories are from Viseu city to Lamego city in a special place called "Kosmos Institute" placed on a mountain in a rural touristic hotel, and focus on grading, seminar learning and tournament. To Faro, for training with Mr. Walter Pestana because he has moved from Viseu to Faro. Of course, to Lisbon for training on the Honbu dojo of the "Internacional de Kung Fu" (Kung Fu International) with Mr. Ruy de Mendonça teaching. And also, to Lisbon for the first contact training with Mr. Jaime S. Pereira of Okinawa Goju-ryuKaratedo in Portugal.

\subsubsection{MA Developing Strong Basis}

After moving to Lisbon from 1984 to 1989 for University Bachelor Studies in Physical Education and Sports, I continued the practice of Goju-ryukaratedo with Jaime S. Pereira in Oeiras-Lisbon, and during that period I travelled to various cities to participate in various Competitions in Porto, Santo Tirso, Beja, Faro, Braga and some other ones various times. This $84-89$ period also included a participation on the European Championships of Goju-ryukaratedo in Belgium_Leopoldsburg in 1987 with an interesting car travel from Lisbon to Leopoldsburg with 6 passengers, my first international trip motivated by Martial Arts. Also, I cannot forget my first published paper on the national Physical Education and Sports magazine (Horizionte) in 1987 and my first published work on Bushido, a magazine for MA in Portugal in 1989.

SECOND CONCLUSIVE COMMENT: I feel this second cycle made me open the understanding and open the mat to construct strong basis on the empirical training for MA skills improvement connected with the beginning of the scientific understanding of MA practice. Travels in Portugal become frequent because of tournaments, in Porto, Santo Tirso, Beja, Faro, Braga. Some travels to other places such as Sintra for seminars in karatedo, judo and aikido. And travels to Belgium (Leopoldsburg) for competition.

\subsubsection{MA Teaching Experiencing Beginnings}

On 1989 I started a professional cycle as Assistant Professor in School of Education in Viseu Polytechnic Institute, continued up to now. From 1989 I started Karate Coaching and Teaching children and youth classes on a private dojo in Viseu city up to 2003. In 1993 I start teaching Adults in Viseu, because some of the children become adults and because other cities want to start karate with me, as in Tondela, and, in 1995, with partners of practice mainly students, I made foundation the "Karate Association of Viseu", and that make an institutional grow to a background for the next steps and connection with International Links and Institutions in Martial Arts practice. In 1993 I started my career as karate referee linked with National Karate Federation and I interrupted officially in 2004. A first international travel with links to learning in Seminars happen in 1995, passing 15 days in Okinawa, participating on the "1995 Okinawan Karate Kobudo World Pre-Tournament" in Naha-Okinawa, and visiting many dojo's of teachers in different cities of Okinawa, and training on them.

I finish my Master Degree in Education Sciences-Methodology of Physical Education, and during those studies I helped the construction of National Karate Federation in 1992 as a federation connecting 
two different past karate governing bodies from previous cycles, and because my background on Sport Sciences (BSc and MSc) regarding management, pedagogy, didactics and methodology, I become responsible to propose Coach Education processes and model construction in the official National Karate Federation involving all the teachers and coaches, and started a new way of doing Coach Education Courses in karatedo, and made many seminars, courses (4 degrees of Courses) and workshops, and organized a team of researchers mainly from Sport Sciences to start a new curricular model to teach Karate Federation Coaches.

THIRD COMMENT: I feel this third cycle made me open the understanding as teacher, technician and researcher responsibilities. Travels have been made inside Portugal for one competition, for learning in seminars in different cities in Portugal but mainly in Lisbon, for teaching in another city (Tondela), for technical meetings because National Karate Federation mainly in Lisbon but also in other cities for Coach Education workshops and courses, as meetings with technical team members. Also, from 1993 on I also travelled because of referee in karate competitions in Portugal. But the first travel with much impact was going to Okinawa - Japan for Competition, Seminars and international grading to 3rd dan.

\subsubsection{MA Expanding Experiences and Focus Practices}

From 1997 to 2009 a fourth cycle happens on my evolution that made me travel with different purposes. In 1997 I started the international travels representing Karate Association of Viseu with the mission to find a new international connection because we have disconnected from the group of Mr. Jaime S. Pereira. In that way, in 1997 I travelled to GojuryuMeibukan top instructor in São Paulo Brazil for a 15 days training on GojuryuKaratedo in April-May. And, in November, I travel to London for an International Seminar with teachers from Japan Karatedo Federation Gojukai, namely Mr. Tasaki and Mr. Shiomi, and this seminar open, up to now, the doors to a strong institutional network of Goju-ryukaratedo because of the number of different "traditional" and "modern" organizations, teachers and practitioners involved on the bases, and the top connections with Japan Karatedo Federation, the first federation constituted on the world and member of World Karate Federation recognized by International Olympic Committee.

From 1998 on I participated on the European annual major events in London (JKF Gojukai July 1999), Oxford, Switzerland, as representative of Portugal making an evolution from 3rd dan graded in 1994 to 2009 as 6th dan, and I organized in Portugal local, national and European events of Goju-ryukaratedo. Also participated in Goju-ryuKaratedoSeiwakai and in JKF Gojukai events in Japan, in different cities as Akita (06), Osaka (07), Fukuoka (08) and Nagoia (09) where I made my 6th dan testing in JKF Gojukai (after grading in SeiwakaiGoju-ryu). I participated on a Seminar in Los Angeles (USA) in November 2007 with Shuji Tasaki and Seiichi Fujiwara, my Japanese teachers in GojuryuKaratedoSeiwakai. In all of them I started to understand the conceptual deepness of good teachers of Seiwakai and JKF Gojukai, and I start to understand in a better format what is the modern culture of the country that forged karatedo. In connection with some open mind seminars I tried in karatedo, I participated in a Patrick McCarthy "International Ryukyu Karate-jutsu Research Society" in Stokholm/Sweden in December 2002 and I promoted a group of seminars in Portugal with him in 2003.

Also on 2006 I finish my PhD thesis analysing the Institutional Development of Martial Arts and main focus on karatedo as study case of mesoscopic modelling construction in institutional analysis in Sports [18,38]. Before and for research purposes for the $\mathrm{PhD}$ thesis I travelled to 16th World Champion in Madrid, Spain (November 2002), to the European Championships in Breman, Germany (May 2003) and to the World Championships of Cadets and Juniors in Marseille, France (October 2003) to apply questionnaires and interview the National Federation Presidents and Technical Responsible persons.

After my PhD thesis I travelled for an international MA\&CS conference my first time to France (Versailles-2006), and start the organization of this kind of conferences in Portugal, so in 2007 and 2009 I organized two International Conferences in Martial Arts and Combat Sports, looking for the connection between partners that enjoy "pen" and "sword" and those movements made me also travel to many conferences around the world important on the next cycle. 
FOUTH COMMENT: I feel this fourth cycle made me understand and construct the fundamentals as an institutional level of teacher (renshi title, karate Coach maximum level-IV, etc.), technician (Coach Education responsibilities in National Federation, Technical President of Karate Association of Viseu, Seiwakai Top Grading responsibilities achieving 6th dan, JKF Gojukai-Portugal responsibilities achieving 6th dan, etc.), director (President of: National Karate Coach Association/Karate Association of Viseu/JKF Gojukai - Portugal, etc.) and researcher responsibilities (Researching for MA Institutional analysis, $\mathrm{PhD}$ in Sport Sciences studying Karate, first International Conference participant and Organizer, etc.). The new movement: travels start also to be as Researcher.

\subsubsection{MA Expertise Development}

From 2009 to 2017, a fifth cycle occurs in MA, increasing the international connections and responsibilities. I have been elected Vice-president of IMACSSS (International Martial Arts and Combat Sports Scientific Society) and nominated one of the 3 Vice-presidents of JKF Gojukai-Europe in 2011.

I travelled 7 times more to Japan for seminars training and to participate on testing panels and referee on the JKF Gojukai annual championships to Japan, mainly to Omagari + Tokyo (2012), Omagari (2013), Omagari + Sendai (2014), Omagari + Beppu (2015) achieving in Omagari my 7th dan GojuryuKaratedoSeiwakai, Omagari (2016), Tokyo (2016) achieving my 7th dan JKF Gojukai, Omagari (2017).I travelled to Hong Kong for a Seminar with Shihan Seiichi Fujiwara in March 2016 for better preparation for my 7th dan test. Also I travelled in Europe 8 times to London for European seminars and being part of JKF Gojukai European Dan Testing Panels as on Seiwakai Dan Testing Panels during seminars such as JKF Gojukai 2010 (September), Seiwakai 2011 (June), JKF Gojukai 2012 (October), Seiwakai 2013 (October), Seiwakai 2014 (October), Seiwakai 2015 (October), Seiwakai 2016 (October), Seiwakai 2017 (October).

I travelled for international MA\&CS Conferences a minimum of 7 more times such as France (Toulouse-2008), Poland (Targowiska-2008), (Rzeszów-2010) and, after Viseu-2011, the IMACSSS developmental Conferences started in Italy (2012-Genova), in Poland (2014-Rzeszów) and in Japan (2013-Tsukuba), (2017-Osaka). Also my Evaluation Experience in Martial Arts PhD studies started internationally as Arguing Functions of Jikkemien Vertonghen PhD. thesis in Brussels Vrije University (2011-Brussels/Belgium), and in Spain as Arguing Functions of Mikel Perez Gutierrez PhD in Léon University (2012-Léon/Spain) and as Arguing Functions of IgnatioTamaritGrancha PhD in Universidad Católica de Valencia San ViventeMártir (2017-Valencia/Spain).

Also I integrated an Erasmus+ research project in Karate called "Sport at School" that involved 6 National official Federations in Karate: Italy, Portugal, France, German, Poland and France, that made me travel various times in Portugal and one time to Italy (2017-Rome/Ostia).

FIFTH COMMENT: I feel this fifth cycle made me start the expertise waking up as MA and karate(achieving kyoshi title, the 7th dan in Goju-ryukaratedoSeiwakai and the difficult 7th dan in JKF Gojukai), technician (Coach Education responsibilities in National Karate Federation, Technical President of Karate Association of Viseu, Seiwakai Top Grading Group responsibilities in Europe with 7th dan in Seiwakai and JKF Gojukai), director (Vice-President of JKF Gojukai-Europe) and Professor \& Researcher (Participation and organizer of International Conferences, Participation in International PhD. Thesis evaluation, Vice-president of IMACSSS) responsibilities. Travels start also to be more frequent as Researcher, and for the first times as international $\mathrm{PhD}$ member of panels in MA research and involving network projects.

\subsubsection{MA Expertise Responsibilities Starting}

From 2018 to nowadays I feel I'm in a sixth cycle in MA, beginning international connections responsibilities mainly after the election for JKF Gojukai-Europe Presidency in 2018 and as Director for Europe of a Goju-ryukaratedoSeiwakai. Because of these new responsibilities I started to be nominated to give National Seminars in other countries such as in Greece (January 2018 and January 2019) and being Assistant Instructor on European Seminars such as in London (October 2018 and October 2019) and 
in Slovakia (May 2019). In Lisbon I've been for the first time an Instructor on the first International Seminar of Seiwakai Europe (Lisbon 2018). I made my 13th travel to Japan in 2018 for Seiwakai World Annual Event in Omagari and for 4thJKF Gojukai Seminar and Tournament in Akita, and in 2019 my 14th travel for Seiwakai event in Omagari and JKF Gojukai event in Nagasaki.

Also regarding IMACSSS International Conference I made a travel to Poland (2018-Rzeszów) and organized in Viseu the 2019 event. An innovative touristic movement started: After the visit of Kentaro Tai from Nagasaki University in October 2016, some colleagues in Martial Arts made cooperative studies travelling and visiting me on my university, such as Carlos Gutierrez, PhD. from León University—Spain in 2018, and Cristiano Barreira, PhD from Sao Paulo University-Brazil in 2019.

SIXTH COMMENT: I feel this sixth cycle that probably will finish on a long challenging future in making me stronger learner on expertise in MA and karatedo as practitioner (working for 8th dan and hanshi challenges), technician (Coach Education responsibilities in National Sport Governing), director (President of JKF Gojukai-Europe and Director of GojuryuKaratedoSeiwakai for Europe) and Professor \& Researcher responsibilities. Travels are on the same groups as past ones, but cooperative studies inter personal researchers are starting.

FINAL COMMENT: The main motivation and purposes of touristic travels started inside the country with evolution to European participation because of competition. Connected with that competitive purposes, a learning and training for gradings motivation make me participate on karate seminars nationally and internationally. After, and linked with those purposes, because of political responsibilities as director, international travels assumed more frequency. Also because researcher and responsibilities as professor in university, participation on international conferences and international panels for $\mathrm{PhD}$ studies stimulate me on more travels around the world.

\subsection{Other Comments of the Respondents}

Not all the respondents shared their general reflections on the sense of further traveling abroad for study or teaching martial arts. Some focus more on domestic activity.

Zbigniew Bujak (8 dan ITF) gave a summary of his activities from 2019. They were as follows.

1. Coaching studies in classes II, I and Master in taekwon-do; 18 January and 30 March 2019, Częstochowa, Poland-lectures.

2. XV Junior World Championships in Taekwon-do;23-27 April 2019, Inzel, Germany—as an observer and second of hisfighter.

3. Lithuanian Sports University; 13-17 May 2019, Kaunas, Lithuania-trip within Erasmus with the offer of conducting combat taekwon-do training.

4. Short arms shooting course "Pistol 1"; 17-18 August 19 in DabrowaBiałostocka, Poland-participant.

5. Active participation during the 2 days intensive training on MastroDefence System technique and tactics; 7-8 September 2019 Warszawa, Poland-participant.

6. Participation during 2 days intensive training on using weapons (knife and stick) in self-defense; 16-17 November 2019, Warszawa, Poland-participant.

7. International Taekwon-do Harmony Course; 30 August-1 September 2019, Lublin, Poland-participant.

8. WAKO Senior World Kickboxing Championships (PF, KL, FC, MF); 23 November-1 December 2019-observation of competitions.

9. Active participation during the 2-day intensive training on the MastroDefence System technique and tactics: "Items of everyday use in self-defence"; 22-23 Feburary 2020, Janów Podlaski, Poland-participant.

He also made the following observations:

"Participation in the training enabled gaining new knowledge, skills and meeting new people from melee circles (Fred Mastro, Harris Samothrakis, Marcin Michalik-Lipka) promoting modern solutions resulting from the analysis of aggressive behaviour or attacks in recent years. Observation of the highest-ranking competitions expands the coaching workshop with the latest trends in taekwon-do and kick-boxing. The shooting course broadens the scope of competences related to the use of weapons, 
the dangers of using them and how to deal with blackmail with short weapons. Conducting theoretical classes forced the systematization of knowledge regarding selected areas of the theory and technology of taekwon-do training." In addition, he notes that "Trips and participation in training enforce self-reflection, broaden the view of the area of hand-to-hand combat, teach humility. They allow you to expand and modify your own coaching workshop."

Roland Maroteaux presented his comments on the legitimacy of staying for a long time for given martial arts studies in a foreign country. His stays range from week to month. Why? "I think the results are better than staying for several years", he replied. "If the stay is short, we focus more on our work ( 6 to $8 \mathrm{~h}$ a day). The brain registers itself and when we get home it stabilizes over the months and years. When you stay in Japan for several years, it's different: you have to work to live, learn a language, have fun from time to time, even meet a Japanese, etc. Martial arts studies are therefore limited in time. This explains why some Westerners, if they intellectually understood why and how martial arts, most do not practice Japanese technique appropriate for theory properly." He also gave the reason for traveling to China: "I went to China twice to understand taijiquan and calligraphy. I am proud that I have inherited a priceless heritage that I am still improving today." Why did he teach in many non-European countries? "I went to different countries to teach: Singapore, Havana (Cuba) Algiers, Biskra, Batna and Mostaganem (Algeria), Tunis (Tunisia), Casablanca and Meknes (Morocco), New York, Denver, Boston (USA), Toronto and Montreal (Canada), Pointe-à-Pitre (Guadeloupe) Antananarivo (Madagascar) Mumbai (India) Sharja and Dubaï (United Arab Emirates) and most European countries. For instance, I did demonstrations and a conference with film projection in the auditorium of the American University of Dubai in 2001. My motivation was to give every doctor the opportunity to understand the mobile stability of the body that is important to everyone. Body verticality in combat. The pleasure of passing on the basic knowledge practiced by the ancients." It is worth mentioning that Dr Maroteaux specializes in this [39].

\section{Analysis of Statements}

The comparison of activities abroad is for the benefit of those whose headquarters are far from Europe-in China, Japan or Korea. In order to obtain further degrees, titles and entitlements, they must undertake these trips, usually many times. How often are these trips made? In the case of judo, multiple trips made to study occurredmainly in Japan. Most often, due to the combination of different roles (player, trainer, activist and researcher), the coach of this particular Olympic sport went away. However, he traveled not only to Japan and not only for judo studies, but also to gain competence in other martial arts and combat sports.

People cultivating traditional Japanese martial arts go to Japan, which is a typical case of a journey to the source. This applies to both samurai traditions and karate, formed in Okinawa. Sometimes, Japanese martial arts are studied by European instructors in other European countries through participation in international seminars or by visiting the school of a given master, and the same applies to other regions. In turn, sometimes, to gain additional competences (such as Chinese medicine and qigong, or taijiquan), a high-level karate or jujutsu instructor travels to China.

Political factors up to 1989 made it difficult for instructors from Poland and other Central and Eastern European countries to travel to Japan or Western countries. Therefore, when given the opportunity, A. Drewniak went there for a 15-month methodological and training internship. Otherwise, it is probably better to take more frequent trips and make shorter stays, as explained by R. Maroteaux. In turn, from socialist Poland, it was possible to go to North Korea before the system's transformation to study taekwon-do ITF there. It is now much more difficult [40].

What are the other travel destinations? For teaching martial arts, masters from Europe usually travel around Europe, which applies equally to judo, jujutsu, karate, kung-fu and taekwon-do teachers. Some, however, mainly travel around their own country. Sometimes, however, these trips are also made for research, conference meetings and congresses of specialized organizations, domestic or foreign. 
In the case of sports activities, these are cyclical trainings, camps, competitions (participation as a trainer, referee, observer, etc.). This is not tourism for pleasure, but non-entertainment, self-realizing tourism.

What is the meaning and what are the effects of these trips? In the case of teachers and trainers, it is often for tangible profit if they do it professionally/commercially. Often, however, as they themselves indicate, they are still learning themselves-they are looking for new knowledge, and masters as its source. They also try to promote their schools and organizations. Above all, however, as A. Figueiredo described it, this "martial arts tourism" is the way to become a high-level master/teacher. These trips are a form of martial arts studies, and are at the same time practical and theoretical. They enable the acquisition of knowledge and skills, also confirmed by certificates of higher master's degrees. According to the statements and declarations cited here, the respondents are convinced (expressed explicitly or implicitly) of the legitimacy of such trips.

\section{Discussion}

Lovers of various martial arts have already traveled to the sources of their martial arts -Chinese [41-44], Japanese [12,26,32], Korean [40,45] or Brazilian [46]. In this case it is similar, but some of the subjects and their martial arts have their global centers in Europe-in Munich [47] or Vienna [35,36]. Despite the fact that a trip to another continent is quite expensive for most people, as many as 10 out of 12 experts $(83.33 \%)$ speaking here took up this challenge. On the other hand, East Asian masters regularly conduct training seminars, including in England, France and Germany, and at such international meetings you can improve your skills under their guidance, which is quite common.

In particular, the first trip to the country of birth of a given martial art is something similar to a pilgrimage. However, in some subcultures, other similar journeys may also have the character of a pilgrimage coupled with cultural immersion, for example to learn about the culture of capoeira dance-fighting [14,46]. In addition to acquiring skills, it is about exploring the specific socio-cultural context. It is worth learning the language and customs of your teachers, for better contact with them and to acquire first-hand knowledge, and to better understand a martial art that one is practicing. In the Japanese martial arts tradition, reaching 7-8 dan is an extraordinary feat, especially for a Westerner, even if he started practicing at the age of five. Mastery, confirmed by high degrees and titles, requires decades of systematic effort and still a lot of luck. It is good to find the best teacher/masters [47] — then the ambition pays off with diligence and perseverance. The most active student will advance, gaining the next ranks the fastest [48]. Trips to out-of-town training are part of this activity [49].

What has the greatest impact on the frequency of foreign trips of martial arts masters, caused by learning or teaching martial arts? First of all, it seems that the overall strategy for operating within the school or organization has been adopted. Mr. and Mrs.Sieber have been running their own private school for many years, which limits their ability to leave. They more often invite other masters to their school. K. Kernspecht and S. Cynarski quite often organize training seminars attended by people from many countries. Especially GM Kernspecht, as a leader of a very large organization, may not be able to visit his students in many clubs in different countries, so they come to him. In turn, GM Maroteaux, teaching the lesser known martial arts, travels alone to teach in many countries. In some cases, as in A. Figueiredo's experience, the teaching is built on the model of teamwork, and teachers start as the nominated assistant teachers of a main teacher, and they become a team of teachers that could not have a main teacher. The same also happens in testing panels for grading, which always have a directive examiner. In sport, however, trips are forced by the training of fighters, sport referees and trainers, camps and competitions. All this educates and enriches the travel-both of the student and the master/teacher [50].

In some martial arts (e.g., aikido, iaido, ITKF karate), passing the appropriate number of training seminars is required for exams for the next grade. This is probably partly due to training (care for the level of technical skills) but could also be because of commercial considerations. Such stimulated activity (the indicator of this variable is the frequency of trips here) is, for example, in favor of aikido 
compared to ITF taekwon-do [13]. R. Maroteaux began his martial arts with aikido. He is very active in this type of tourism - first he studied traditional martial arts, and then he taught them himself.

\section{Conclusions}

None of the respondents pointed to the material forms of cultural heritage of martial arts as motives for trips. Thus, visiting historic buildings and exercise rooms [4,5] is marginal here. This more passive form of martial arts tourism, closer to standard cultural tourism, has no direct link to career paths and self-improvement in martial arts. Cognitive goals related to martial arts practice (techniques, teaching methodology) prevail.

Author Contributions: For research articles with several authors, a short paragraph specifying their individual contributions must be provided. The following statements should be used "Conceptualization, W.J.C. and A.A.F.; methodology, W.J.C.; software, A.A.F.; validation, W.J.C., A.A.F. and Z.B.; formal analysis, W.J.C. and W.B.; investigation, A.A.F., W.B., Z.B., R.J.M. and W.J.C.; resources, A.A.F., W.B., Z.B., R.J.M. and W.C; data curation, A.A.F., W.B., Z.B., R.J.M. and W.C; writing — original draft preparation, W.J.C.; writing-review and editing, A.A.F. and Z.B.; visualization, W.B. and R.J.M.; supervision, W.B. and W.J.C.; project administration, W.J.C.; funding acquisition, W.B. All authors have read and agreed to the published version of the manuscript.

Funding: This research received no external funding.

Conflicts of Interest: The authors declare no conflict of interest.

\section{Abbreviations}

$\begin{array}{ll}\text { DDBV } & \text { Deutscher Dan-Träger und Budo-Lehrer Verbande.V. German Dan Holders (Black Belts) and } \\ & \text { Budo-Teachers Association } \\ \text { DJJR } & \text { Deutscher Jiu-Jitsu Ring "Erich Rahn"e.V.- German Jiu-Jitsu Ring “Erich Rahn" } \\ \text { ECh } & \text { European Championships } \\ \text { EJU } & \text { European Judo Union } \\ \text { EWTO } & \text { European WingTsunOrganisation } \\ \text { IJF } & \text { International Judo Federation } \\ \text { IPA } & \text { Idokan Poland Association } \\ \text { ITF } & \text { International Taekwon-do Federation } \\ \text { ITKF } & \text { International Traditional Karate Federation } \\ \text { JKF } & \text { Japan Karatedo Federation } \\ \text { MA } & \text { Martial arts } \\ \text { PUT } & \text { PolskaUnia Takeda-ryu-Polish Takeda-ryu Union } \\ \text { WCh } & \text { World Championships } \\ \text { WTF } & \text { World Taekwondo Federation } \\ \text { WTMF } & \text { World Takeda-Ryu Marotokan Federation } \\ \text { WT } & \text { World Taekwondo }\end{array}$

\section{References}

1. Urry, J. The Tourist Gaze: Leisure and Travel in Contemporary Societies; Sage Publications Ltd.: London, UK, 1990.

2. Munsters, W.; Melkert, M. (Eds.) Anthropology as a Driver for Tourism Research; GarantUitgeversn.v.: Antwerpen, Belgium, 2015; ISBN 978-90-441-3242-7.

3. Parker, S.R. The Sociology of Leisure; Allen \& Unwin: London, UK, 1976.

4. Przecławski, K. Człowiek a turystyka. Zaryssocjologiiturystyki (Man and Tourism. Outline of the Sociology of Tourism), 2nd ed.; Albis: Kraków, Poland, 2004.

5. Malchrowicz-Mosko, E.; Munsters, W. Sport tourism: A growth market considered from a cultural perspective. Ido Mov. Cult. J. Martial Arts Anthropol. 2018, 18, 25-38. [CrossRef]

6. Kaur, S.; Kaur, M. Behavioral intentions of heritage tourists: Influential variables on recommendations to visit. J. Herit. Tour. 2020, 15, 511-532. [CrossRef]

7. Cynarski, W.J. Spotkania, Konflikty, Dialogi. Analizawybranychobszarówkulturyfizycznejiturystykikulturowej (Meetings, Conflicts, Dialogues: Analysis of Selected Areas of Physical Culture and Cultural Tourism), 2nd ed.; Rzeszow University Press: Rzeszów, Poland, 2010. 
8. Donohue, J.J. Training Halls of the Japanese Martial Tradition: A Symbolic Analysis of Budo Dojo in New York. Anthropos 1990, 85, 55-63.

9. Cynarski, W.J. Architektura a antropologiadalekowschodnichsztukwalki: Architekturadōjō—szkic z socjologiiprzestrzeni [Architecture and the anthropology of Far Eastern martial arts: Dōjō architecture—sketch of space sociology]. Ido Mov. Cult. 2005, 5, 75-95.

10. Obodyński, K. Encounters, conflicts, dialogues. Analysis of selected areas of physical culture and cultural tourism (a review). Eur. J. Tour. Res. 2008, 1, 161-163.

11. Obodyński, K.; Cynarski, W.J. (Eds.) International Dialogue: Global, European, National and Multicultural Dimensions of Tourism; European Academy for the Carpathian Euroregion (EACE): Rzeszów, Poland, 2005; ISBN 83-89721-07-4.

12. Obodyński, K.; Cynarski, W.J.; Litwiniuk, A. Self-educational tourism on the way of budō. In International Dialogue: Global, European, National and Multicultural Dimensions of Tourism; European Academy for the Carpathian Euroregion (EACE): Rzeszów, Poland, 2005; pp. 165-181.

13. Litwiniuk, A.; Cynarski, W.J.; Piech, K. Sport and recreational activities as a way to promote travelling basing on meetings, seminars and sport camps of sports and martial arts. In International Dialogue: Global, European, National and Multicultural Dimensions of Tourism; EACE: Rzeszów, Poland, 2005; pp. 182-185.

14. Cynarski, W.J. Tourism of Martial Arts: Social-Cultural Perspective; Rzeszow University Press: Rzeszów, Poland, 2020.

15. Błach, W.; Świder, P.; Sieber, L. Tourism of martial arts: The inspiration for Prof. Cynarski's new book. Ido Mov. Cult. J. Martial Arts Anthropol. 2020, 20, 47-52. [CrossRef]

16. Grady, J. Visual research at the crosroads. Forum Qual. Soc. Res. 2008, 9, 3. [CrossRef]

17. Cynarski, W.J. Martial Arts $\mathcal{E}$ Combat Sports: Towards the General Theory of Fighting Arts; WydawnictwoNaukoweKatedra: Gdańsk, Poland, 2019; ISBN 978-83-66107-17-5.

18. Figueiredo, A. The object of study in martial arts and combat sports research-contributions to a complex whole. In Martial Arts and Combat Sports-Humanistic Outlook; Rzeszow University Press: Rzeszów, Poland, 2009; pp. 20-34.

19. Girton, G.D. Kung Fu: Toward a Praxiological Hermeneutic of the Martial Arts. In Ethnomethodological Studies of Work; Routledge \& Kegan Paul: London, UK, 1986.

20. Stoleroff, A.D. ProfissãoouVocação: Instrutores de Karatéem Portugal (Profession or Vocation: Karate Instructors in Portugal). In Proceedings of the Abstract on the IV Portuguese Sociology Congress, Coimbra, Portugal, 17-19 April 2000.

21. Wacquant, L. Corps et Âme-Carnets Ethnographiques d'un ApprentiBoxeur; Agone/Comeau et Nadeau: Marseille, France, 2000.

22. Ślęzak, M. Zastosowaniewywiadunarracyjnegonagrunciesocjologiikulturyfizycznej (zeszczególnymuwzg lędnieniemdalekowschodnichsztukwalki) (The use of narrative interview on the basis of sociology of physical culture (with particular emphasis on Far Eastern martial arts)). Ido Mov. Cult. 2006, 6, 34-41.

23. Green, T.A.; Markowska, S.S.; Cynarski, W.; García, C.G.; Figueiredo, A.; Simenko, J. Qualitative and quantitative methods in the study of martial arts and combat sports: A panel based on personal experiences. Rev. Artes MarcialesAsiáticas 2019, 14, 79-83. [CrossRef]

24. Richards, G.; Munsters, W.; Dekker, T.; Hayllar, B.; Oviedo-García, M.Á.; Darcy, S.; Fox, D.D. Cultural Tourism Research Methods; CABI: Cambridge, UK, 2010.

25. Błach, W.; EJU, Wrocław, Poland; Cynarski, W.J.; University of Rzeszów, Rzeszów, Poland. Personal communication, 2016.

26. Cynarski, W.J. Tourism of martial arts as sport tourism, on example from judo and jujutsu. Sci. Rev. Phys. Cult. 2017, 7, 50-55.

27. Świder, P. Aikido and Judo in teaching of shihan Wojciech J. Cynarski. Ido Mov. Cult. J. Martial Arts Anthropol. 2018, 18, 8-14. [CrossRef]

28. Shihan Andrzej Drewniak. Available online: http://www.karate.org.pl/kyokushin/hist_drewniak.php (accessed on 28 March 2020).

29. Kernspecht, K.R. Inner WingTsun; EWTO-Verlag: Heielberg, Germany, 2014.

30. Filipiuk, J. Uratował Golotę Przed Sportowym Niebytem. Available online: https://plus.gazetakrakowska.pl/ uratowal-golote-przed-sportowym-niebytem/ar/11902534 (accessed on 28 August 2020).

31. Popko, K.; Polskie Radio WPNA, Chicago, IL, USA; Samitowski, L.; Kanku School, Chicago, IL, USA. Personal communication, 2019. 
32. Sieber, L.; Sieber, H. Japan reisealsGeschenkzum 30-jaerigen Jubilaum der JiuJitsu- und Karate-Schule Lothar Sieber [Travel to Japan as a gift for the 30th anniversary of the JiuJitsu and Karate School Lothar Sieber]. Budo-Info Ber. Mein. Inf. 2006, 1, 5-11.

33. Sieber, L.; Cynarski, W.J.; Litwiniuk, A. Coming into being of the martial arts tourism. Ido Mov. Cult. 2007, 7, 167-173.

34. Strauss, F.; Słopecki, J. The way of life and the way of martial arts. Ido Mov. Cult. J. Martial Arts Anthropol. 2014, 14, 72-76. [CrossRef]

35. Cynarski, W.J.; Słopecki, J. Way of the warrior jūjutsu. Interview with dr Jan Słopeckihanshi. Sci. Rev. Phys. Cult. 2015, 5, 47-53.

36. Słopecki, J. Jujutsu Seminar in Vienna at WadoTeJutsu School of Franz Strauss. Presentation of Expert-Professor Medal and Diploma to Extraordinary Teacher of Jujutsu and Judo-do Ido. Ido Mov. Cult. J. Martial Arts Anthropol. 2012, 12, 41-44.

37. Słopecki, J.; Bruns, H. Super Seminar: Training seminar and research internship at the German Sportschule Tao sports club, Aurich, 11-13.06.2011. Ido Mov. Cult. J. Martial Arts Anthropol. 2011, 12, 49-52.

38. Figueiredo, A. Martial Arts and Combat Sports Coaching. International Framework and Sport Sciences Challenges. Available online: https://www.researchgate.net/publication/308755019_Martial_ arts_and_combat_sports_coaching_International_framework_and_sport_sciences_challenges (accessed on 24 August 2020).

39. Maroteaux, R.J. The Mobile Stability of the Body (Traditional Martial Arts and Combat Sports); Autoedition: Avignon, France, 2012.

40. Cynarski, W.J.; Johnson, J.A. North Korea's emerging martial arts tourism: A Taekwon-Do case study. Int. J. Cult. Tour. Hosp. Res. 2020, 14, 667-680. [CrossRef]

41. Albrecht, M.; Rudolph, F. Wu-Ein Deutscherbei den Meistern in China [Wu-German at the Masters in China]; Palisander: Chemnitz, Germany, 2011.

42. Raimondo, S. Heritage tourism and Taijiquan: The case of Chenjiagou, Henan, RPC. Ido Mov. Cult. J. Martial Arts Anthropol. 2011, 11, 52-59.

43. Antonowicz, P.; Dzieciątko, A. Chińskie sztuki walki w Chenjiagou-refleksje z wypraw do źródeł powstania stylu Chen Tai Chi Chuan. In Gdańskie Studia Azji Wschodniej; Wydawnictwo Uniwersytetu Jagiellońskiego: Kraków, Poland, 2016; pp. 167-178.

44. Skowron-Markowska, S. Chinese guóshù (國術 “national art”) in Shaolin Temple. Ido Mov. Cult. J. Martial Arts Anthropol. 2019, 19, 25-31. [CrossRef]

45. Park, T.S. Academic convergence of taekwondo and tourism in Korea. Asia Life Sci. 2019, 1085-1092.

46. Griffith, L.M. Beyond Martial Arts Tourism: Outcomes of Capoeiristas' Apprenticeship Pilgrimages. Ido Mov. Cult. J. Martial Arts Anthropol. 2016, 16, 32-40. [CrossRef]

47. Cynarski, W.J.; Sieber, L.; Mytskan, T. Study trip to Munich. Casus of scientific and martial arts tourism. Ido Mov. Cult. J. Martial Arts Anthropol. 2015, 15, 49-57. [CrossRef]

48. Cynarski, W.J.; Yu, J.-H.; Pawelec, P. Changes in the level of physical fitness on the way to mastery in martial arts according to activity. Ido Mov. Cult. J. Martial Arts Anthropol. 2017, 17, 38-44. [CrossRef]

49. Pawelec, P.; Świder, P.; Cynarski, W.J. Martial Arts Tourism: Meta-Analysis of Publications from 2005-2020. Sustainability 2020, 12, 7069. [CrossRef]

50. Arziutov, G.; Iermakov, S. The use of didactic laws in the teaching of the physical elements involved in judo techniques. Ido Mov. Cult. J. Martial Arts Anthropol. 2016, 21-30. [CrossRef]

Publisher's Note: MDPI stays neutral with regard to jurisdictional claims in published maps and institutional affiliations.

(C) 2020 by the authors. Licensee MDPI, Basel, Switzerland. This article is an open access article distributed under the terms and conditions of the Creative Commons Attribution (CC BY) license (http://creativecommons.org/licenses/by/4.0/). 